\title{
GAMBARAN KEMATIAN IBU DI WILAYAH KABUPATEN TASIKMALAYA \\ TAHUN 2014
}

Oleh :

H Aam Nursalam, SKM,MMKes dan Teni Supriyani, S.KM,M.KM

\section{A. Abstrak}

Berdasarkan data hasil Survei Demografi Kesehatan Indonesia (SDKI) tahun 2012, Angka Kematian Ibu (AKI) di Indonesia mencapai 359 per 100.000 kelahiran hidup dan Angka Kematian Bayi (AKB) mencapai 32 per 1000 kelahiran hidup. Sedangkan di wilayah Provinsi Jawa Barat data kematian ibu di Jawa Barat pada 2013 adalah 781 kasus dan pada tahun 2014 turun menjadi 747 kasus. Di wilayah Kabupaten Tasikmalaya pada tahun 2014 jumlah kematian ibu adalah 31 orang. Tujuan dari penelitian ini adalah mengetahui gambaran jumlah kematian ibu berdasarkan tahahapan dan usia di wilayah Kabupaten Tasikmalaya tahun 2014.

Jenis penelitian yang digunakan adalah kuantitatif dengan metode deskriptif. Populasi penelitian ini adalah seluruh ibu yang meninggal pada saat hamil, melahirkan dan nifas di wilayah Kabupaten Tasikmalaya tahun 2014. Tehnik pengambilan sampel dilakukan secara total sampling. Tehnik pengambilan data dilakukan dengan cara studi data sekunder laporan Dinas Kesehatan Kabupaten tasikmalaya Tahun 2015. Tehnik analisis data menggunakan analisis univariat.

Berdasarkan hasil penelitian didapatkan bahwa didapatkan bahwa kematian ibu pada tahun 2014 di wilayah Kabupaten Tasikmalaya adalah 31 orang. Distribusi kematian ibu berdasarkan kecamatan yang paling banyak yaitu Kecamatan Cikalong dan Salopa yaitu 3 orang atau 0.96\%. Kematian ibu di wilayah Kabupaten Tasikmalaya tahun paling banyak terjadi pada tahapan bersalin yaitu 13 orang atau 41,96\%. Serta kematian ibu di wilayah Kabupaten Tasikmalaya tahun 2014 paling banyak terjadi pada usia 20 - 35 tahun yaitu 24 orang atau $77.4 \%$.

Disarankan instansi kesehatan dapat meningkatkan kualitas pelayanan kesehatan ibu dan anak dimulai dari ANC, APN dan asuhan masa nifas.

Kata Kunci: Kematian ibu, tahapan hamil, bersalin dan nifas serta usia. 


\section{B. Latar Belakang}

Mortalitas dan morbiditas pada wanita hamil dan bersalin adalah masalah besar di negara berkembang. Negara berkembang menyumbang 99\% dari total kematian ibu(Guiterrez et all 2007). Kematian saat melahirkan biasanya menjadi faktor utama mortalitas (Saefudin, 2002). Kematian ibu ini biasanya disebut kematian maternal yaitu kematian perempuan hamil atau kematian dalam 42 hari setelah berakhirnya kehamilan tanpa mempertimbangkan umur dan jenis kehamilan, sebagai komplikasi persalinan atau nifas, dengan penyebab terkait atau diperberat oleh kehamilan dan manajemen kehamilan, tetapi bukan karena kecelakaan (Kadour, 2008).

Berdasarkan data hasil Survei Demografi Kesehatan Indonesia (SDKI) tahun 2012, Angka Kematian Ibu (AKI) di Indonesia mencapai 359 per 100.000 kelahiran hidup dan Angka Kematian Bayi (AKB) mencapai 32 per 1000 kelahiran hidup. Sedangkan di wilayah Provinsi Jawa Barat data kematian ibu di Jawa Barat pada 2013 adalah 781 kasus dan pada tahun 2014 turun menjadi 747 kasus.

Kematian ibu merupakan peristiwa kompleks yang disebabkan oleh berbagai penyebab Penyebab kematian ibu yang paling umum di Indonesia adalah penyebab obstetri langsung yaitu perdarahan $28 \%$, preeklampsi/eklampsi $24 \%$, infeksi $11 \%$, sedangkan penyebab tidak langsung adalah trauma obstetri $5 \%$ dan lain - lain $11 \%$ (WHO, 2007). Determinan dekat yang berhubungan langsung dengan kematian ibu merupakan gangguan obstetrik seperti perdarahan, preeklamsi/eklamsi, dan infeks atau penyakit yang diderita ibu sebelum atau selama kehamilan yang dapat memperburuk kondisi kehamilan seperti jantung, malaria, tuberkulosis, ginjal, dan acquired immuno-deficiency syndrome dan perilaku penggunaan fasilitas kesehatan. Determinan jauh berhubungan dengan faktor demografi dan sosiokultural. Kesadaran masyarakat yang rendah tentang kesehatan ibu hamil, pemberdayaan perempuan yang tidak baik, latar belakang pendidikan, sosial ekonomi keluarga, lingkungan masyarakat dan politik, serta kebijakan secara tidak langsung diduga ikut berperan dalam meningkatkan kematian ibu.

Untuk menurunkan AKI, Kementerian Kesehatan Republik Indonesia mencanangkan Making pregnancy Safer (MPS), antara lain terimplementasi dalam program Jampersal untuk menjamin semua persalinan dilakukan di fasilitas kesehatan dan oleh tenaga kesehatan terlatih serta penyediaan pelayanan obstetri neonatal emergensi dasar (PONED) dan pelayanan obstetri neonatal emergensi komprehensif (PONEK) untuk menjamin semua komplikasi obstetrik dapat tertangani dengan optimal. Selain itu, Kementerian Negara Pemberdayaan Perempuan juga mencanangkan Gerakan Sayang Ibu (GSI) sebagai upaya menumbuhkan kesadaran bahwa kehamilan dan kelahiran dapat memunculkan risiko dan tidak hanya menjadi tanggung jawab ibu, tetapi juga juga keluarga, suami, orang tua, dan masyarakat.

Berdasarkan latar belakang diatas peneliti bermaksud untuk melakukan penelitian dengan judul " gambaran kasus kematian ibu di wilayah Kabupaten Tasikmalaya tahun 2014"

\section{Metode}

Jenis penelitian yang digunakan adalah kuantitatif dengan metode deskriptif. Populasi penelitian ini adalah seluruh ibu yang meninggal pada saat hamil, melahirkan dan nifas di wilayah Kabupaten Tasikmalaya tahun 2014. Tehnik pengambilan sampel dilakukan secara total sampling. Tehnik 
pengambilan data dilakukan dengan cara studi data sekunder laporan Dinas Kesehatan Kabupaten tasikmalaya
Tahun 2015. Tehnik analisis data menggunakan analisis univariat.

\section{Hasil penelitian}

Berdasarkan hasil penelitian didapatkan bahwa :

1. Jumlah kematian ibu di Wilayah Kabupaten Tasikmalaya Tahun 2014

Tabel 5.1

Distribusi Kematian ibu berdasarkan Kecamatan di Wilayah Kabupaten Tasikmalaya Tahun 2014

\begin{tabular}{|c|l|c|r|}
\hline NO & \multicolumn{1}{|c|}{ KECAMATAN } & F & \% \\
\hline 1 & Cipatujah & 1 & 0.032 \\
\hline 2 & Karangnunggal & 2 & 0.064 \\
\hline 3 & Cikalong & 3 & 0.096 \\
\hline 4 & Pancatengah & 0 & 0 \\
\hline 5 & Cikatomas & 1 & 0.032 \\
\hline 6 & Cibalong & 0 & 0 \\
\hline 7 & Parungponteng & 0 & 0 \\
\hline 8 & Bantarkalong & 1 & 0.032 \\
\hline 9 & Bojongasih & 0 & 0 \\
\hline 10 & Culamega & 0 & 0.032 \\
\hline 11 & Bojonggambir & 1 & 0.064 \\
\hline 12 & Sodonghilir & 2 & 0.032 \\
\hline 13 & Taraju & 1 & 0.032 \\
\hline 14 & Salawu & 1 & 0.064 \\
\hline 15 & Puspahiang & 2 & 0.032 \\
\hline 16 & Tanjungjaya & 1 & 0.032 \\
\hline 17 & Sukaraja & 0 & 0.096 \\
\hline 18 & Salopa & 0 & 0 \\
\hline 19 & Jatiwaras & 1 & 0.032 \\
\hline 20 & Cineam & 0 & 0 \\
\hline 21 & Karangjaya & 0 & 0 \\
\hline 22 & Manonjaya & 0 & 0 \\
\hline 23 & Gunungtanjung & 0 & 0 \\
\hline 24 & Singaparna & 0 & 0 \\
\hline & & 0 & 0 \\
\hline
\end{tabular}




\begin{tabular}{|c|c|c|c|}
\hline 25 & Mangunreja & 0 & 0 \\
\hline 26 & Sukarame & 1 & 0.032 \\
\hline 27 & Cigalontang & 2 & 0.064 \\
\hline 28 & Leuwisari & 0 & 0 \\
\hline 29 & Padakembang & 1 & 0.032 \\
\hline 30 & Sariwangi & 2 & 0.064 \\
\hline 31 & Sukaratu & 0 & 0 \\
\hline 32 & Cisayong & 0 & 0 \\
\hline 33 & Sukahening & 0 & 0 \\
\hline 34 & Rajapolah & 0 & 0 \\
\hline 35 & Jamanis & 0 & 0 \\
\hline 36 & Ciawi & 0 & 0 \\
\hline 37 & Kadipaten & 2 & 0.064 \\
\hline 38 & Pagerageung & 1 & 0.032 \\
\hline 39 & Sukaresik & 0 & 0 \\
\hline
\end{tabular}

Berdasarkan tabel 5.1 didapatkan bahwa kematian ibu pada tahun 2014 di wilayah Kabupaten Tasikmalaya adalah 31 orang. Distribusi kematian ibu berdasarkan kecamatan yang paling banyak yaitu Kecamatan Cikalong dan Salopa yaitu 3 orang atau $0.96 \%$.

2. Jumlah kematian ibu berdasarkan tahapan di Wilayah Kabupaten Tasikmalaya Tahun 2014

Tabel 5.2

Distribusi Kematian ibu berdasarkan tahapan di Wilayah Kabupaten Tasikmalaya Tahun 2014

\begin{tabular}{|c|c|c|c|}
\hline NO & TAHAPAN & $\mathbf{F}$ & $\%$ \\
\hline 1 & Kehamilan & 12 & 38.70 \\
\hline 2 & Bersalin & 13 & 41.93 \\
\hline 3 & Nifas & 6 & 19.35 \\
\hline & Jumlah & 31 & 100 \\
\hline
\end{tabular}

Berdasarkan tabel 5.2 didapatkan bahwa kematian ibu di wilayah Kabupaten Tasikmalaya tahun 2014 paling banyak terjadi pada tahapan bersalin yaitu 13 orang atau $41,96 \%$.
3. Jumlah kematian ibu berdasarkan usia ibu di Wilayah Kabupaten Tasikmalaya Tahun 2014 
Tabel 5.3

Distribusi Kematian ibu berdasarkan usia ibu Kecamatan di Wilayah Kabupaten Tasikmalaya Tahun 2014

\begin{tabular}{|c|l|c|r|}
\hline NO & \multicolumn{1}{|c|}{ USIA } & F & \multicolumn{2}{|c|}{$\%$} \\
\hline 1 & Kurang dari 20 tahun & 1 & 3.22 \\
\hline 2 & $20-35$ tahun & 24 & 77.4 \\
\hline 3 & Lebih dari 35 tahun & 6 & 19.35 \\
\hline & Jumlah & 31 & \\
\hline
\end{tabular}

Berdasarkan tabel 5.3 didapatkan bahwa kematian ibu di wilayah Kabupaten Tasikmalaya tahun 2014

\section{E. Pembahasan}

\section{Kematian ibu}

Berdasarkan hasil penelitian didapatkan bahwa kematian ibu pada tahun 2014 di wilayah Kabupaten Tasikmalaya adalah 31 orang. Distribusi kematian ibu berdasarkan kecamatan yang paling banyak yaitu Kecamatan Cikalong dan Salopa yaitu 3 orang atau $0.96 \%$.

Pada International Statistical Classification of Diseases and Related Health Problems, Tenth Revision, 1992 (ICD-10), WHO mendefinisikan kematian maternal adalah kematian seorang wanita saat masa hamil atau dalam 42 hari setelah terminasi kehamilan, terlepas dari durasi dan lokasi kehamilan, dari setiap penyebab yang berhubungan dengan atau diperburuk oleh kehamilan atau pengelolaannya, tetapi bukan dari sebab-sebab kebetulan atau insidental (WHO, 2007).

Kematian ibu dibagi menjadi kematian langsung dan tidak langsung. Kematian ibu langsung adalah sebagai akibat komplikasi kehamilan, persalinan, atau masa nifas, dan segala intervensi atau penanganan tidak tepat dari komplikasi tersebut. Kematian ibu tidak langsung adalah paling banyak terjadi pada usia $20-35$ tahun yaitu 24 orang atau $77.4 \%$.

merupakan akibat dari penyakit yang sudah ada atau penyakit yang timbul sewaktu kehamilan yang berpengaruh terhadap kehamilan, misalnya malaria, anemia, HIV/AIDS, dan penyakit kardiovaskular (Prawirohardjo, 2008).

Klasifikasi kematian ibu ada tiga, yaitu kematian ibu langsung, kematian ibu tidak langsung, dan kematian nonmaternal. Kematian ibu langsung mencakup kematian ibu akibat penyulit obstetri pada kehamilan, persalinan, atau masa nifas, dan akibat dari intervensi, kelalaian, kesalahan terapi, atau rangkaian kejadian yang disebabkan oleh faktor-faktor tersebut.

Contohnya adalah kematian ibu akibat perdarahan karena ruptur uteri. Kematian ibu tidak langsung mencakup kematian ibu yang tidak secara langsung disebabkan oleh kausa obstetri, melainkan akibat penyakit yang sudah ada sebelumnya, atau suatu penyakit yang timbul saat hamil, melahirkan, atau masa nifas, tetapi diperberat oleh adaptasi fisiologis ibu terhadap kehamilannya.

Contohnya adalah kematian ibu akibat penyulit stenosis mitral. Kematian nonmaternal adalah kematian ibu yang terjadi akibat kecelakaan atau kausa insidental yang 
tidak berkaitan dengan kehamilan. Contohnya adalah kematian akibat kecelakaan lalu lintas (Cunningham, 2005). kematian ibu akibat penyulit obstetri pada kehamilan, persalinan, atau masa nifas, dan akibat dari intervensi, kelalaian, kesalahan terapi, atau rangkaian kejadian yang disebabkan oleh faktor-faktor tersebut.

Contohnya adalah kematian ibu akibat perdarahan karena ruptur uteri. Kematian ibu tidak langsung mencakup kematian ibu yang tidak secara langsung disebabkan oleh kausa obstetri, melainkan akibat penyakit yang sudah ada sebelumnya, atau suatu penyakit yang timbul saat hamil, melahirkan, atau masa nifas, tetapi diperberat oleh adaptasi fisiologis ibu terhadap kehamilannya. Contohnya adalah kematian ibu akibat penyulit stenosis mitral. Kematian nonmaternal adalah kematian ibu yang terjadi akibat kecelakaan atau kausa insidental yang tidak berkaitan dengan kehamilan. Contohnya adalah kematian akibat kecelakaan lalu lintas (Cunningham, 2005).

\section{Kematian ibu pada masa bersalin}

Berdasarkan tabel 5.2 didapatkan bahwa kematian ibu di wilayah Kabupaten Tasikmalaya tahun 2014 paling banyak terjadi pada tahapan bersalin yaitu 13 orang atau $41,96 \%$.

Hal ini sesuai dengan data pada akhir tahun 2015, WHO melaporkan setidaknya 303,000 wanita di seluruh dunia meninggal menjelang dan selama proses persalinan. Di Indonesia sendiri, sepanjang tahun 2011-2015 terdapat 126 kasus kematian ibu tiap 100,000 proses persalinan sukses. Angka yang ditunjukkan oleh WHO tahun 2008 menyatakan bahwa perdarahan saat persalinan adalah penyebab ketiga paling umum dari kematian ibu di negara-negara berpenghasilan rendah (setelah HIV/AIDS dan TBC), dan tercatat hingga 58.000 kematian.
Dikutip dari thelancet.com, sekelompok peneliti menunjukkan bahwa sepanjang tahun 2003 hingga 2009, perdarahan, gangguan hipertensi (preeklampsia dan eklampsia), dan sepsis merupakan penyebab lebih dari setengah kematian ibu di seluruh dunia. Lebih dari seperempat dari angka kematian disebabkan penyebab tidak langsung, seperti infeksi pascamelahirkan, komplikasi aborsi, komplikasi persalinan, dan pembekuan darah.

Akumulasi dari sejumlah faktor risiko di atas tercatat memiliki peran dalam kematian ibu di seluruh dunia hingga $80 \%$.Walaupun angka mortalitas ibu telah menurun drastis sejak 1990-an (hingga 45 persen), namun hampir 99 persen dari keseluruhan kasus mortalitas ibu yang dilaporkan oleh World Health Organization (WHO) berasal dari negara-negara berkembang yang memiliki pengaturan sumber daya rendah, termasuk Indonesia.

Sebenarnya, sebagian besar penyebab kematian ibu dapat dicegah. Salah satunya adalah jika pemerintah menyediakan sistem kesehatan yang mudah dijangkau oleh semua ibu di berbagai pelosok daerah, dan dengan biaya yang relatif murah, sebagai solusi pencegahan dan penanganan darurat dari segala komplikasi kehamilan dan persalinan.

Langkah-langkah utama yang telah terbukti membantu mengurangi angka mortalitas ibu, meliputi:

1. Memastikan setiap wanita mendapatkan akses mudah, cepat, dan berkualitas tinggi terhadap perawatan prenatal menjelang persalinan (setidaknya 4 kali konsultasi dokter selama masa kehamilan).

2. Memastikan setiap wanita mendapatkan akses terhadap tenaga keperawatan (dokter bersalin, bidan bersertifikat, suster profesional) yang terampil saat persalinan dan 
perawatan beberapa minggu setelah proses persalinan usai.

3. Memastikan akses yang mudah terhadap rumah sakit atau klinik persalinan yang berkualitas. Risiko dapat dikurangi secara signifikan jika masalah pada kehamilan dapat ditanggulangi sejak dini dan jika wanita dapat menjalani persalinan bayi mereka di klinik kesehatan yang lengkap atau rumah sakit dengan bidan terlatih dan dokter untuk membantu.

4. Akses dan pemberdayaan program Keluarga Berencana.

Perdarahan hebat setelah lahir dapat membunuh seorang ibu yang sehat dalam beberapa jam saja jika dibiarkan tanpa pengawasan. Menyuntikkan oksitosin segera setelah melahirkan juga secara efektif mengurangi risiko perdarahan.

Infeksi setelah melahirkan bisa dieliminasi jika kebersihan yang baik dijaga dengan ketat selama proses kelahiran dan jika tanda-tanda awal infeksi dapat dideteksi dan ditanggulani secara tepat waktu.

Preeklampsia harus dideteksi dan dikelola dengan baik sebelum timbul kejang (eklampsia) dan komplikasi yang mengancam jiwa lainnya. Pemberian

\section{F. Simpulan dan saran \\ Simpulan}

Berdasarkan hasil penelitian didapatkan bahwa didapatkan bahwa kematian ibu pada tahun 2014 di wilayah Kabupaten Tasikmalaya adalah 31 orang. Distribusi kematian ibu berdasarkan kecamatan yang paling banyak yaitu Kecamatan Cikalong dan Salopa yaitu 3 orang atau $0.96 \%$. Kematian ibu di wilayah Kabupaten Tasikmalaya tahun paling banyak terjadi pada tahapan bersalin yaitu 13 orang atau $41,96 \%$. Serta kematian ibu obat-obatan seperti magnesium sulfat untuk preeklampsia dapat menurunkan risiko wanita terkena eklampsia.

Untuk menghindari kematian ibu, penting juga untuk mencegah kehamilan yang tidak diinginkan dan terlalu dini. Semua wanita, termasuk remaja perempuan, memerlukan akses ke kontrasepsi, layanan aborsi resmi yang dilakukan oleh dokter dan dilindungi hukum untuk kasus-kasus kehamilan yang tidak diinginkan, dan perawatan kesehatan yang terjamin.

Kesehatan ibu dan bayi adalah dua hal yang saling berkaitan satu sama lain. Sekitar 2,7 juta bayi yang baru lahir meninggal setiap tahunnya, dan tambahan 2,6 juta lainnya meninggal dalam kandungan. Sangat penting untuk memastikan bahwa semua kelahiran dapat dibantu oleh tenaga profesional kesehatan yang terampil, sehingga jika ditemukan masalah akan dapat ditanggulangi tepat waktu. Hal ini dapat membuat perbedaan antara hidup dan mati bagi ibu dan bayi.

Berdasarkan tabel 5.3 didapatkan bahwa kematian ibu di wilayah Kabupaten Tasikmalaya tahun 2014 paling banyak terjadi pada usia $20-35$ tahun yaitu 24 orang atau $77.4 \%$.

di wilayah Kabupaten Tasikmalaya tahun 2014 paling banyak terjadi pada usia 20 - 35 tahun yaitu 24 orang atau $77.4 \%$.

\section{Saran}

\section{a. Bagi instansi kesehatan}

Meningkatkan kualitas pelayanan kesehatan ibu dan anak dimulai dari ANC, APN dan asuhan masa nifas.

\section{b. Bagi masyarakat}

Meningkatkan pengetahuan dengan mencari informasi tentang kesehatan ibu dengan segala faktor resikonya. 


\section{G. Referensi}

World Health Organization. Trends in maternal mortality: 1999 to 2008.Geneva: World Health Organization press; 2010.

Herawati I. Analisis kematian ibu di Indonesia tahun 2010 berdasarkandata SDKI, Riskesdas, dan laporan rutin kesehatan ibu dan anak.Pertemuan Teknis Kesehatan Ibu; 6 April 2011; Bandung, Indonesia.Jakarta: Departemen Kesehatan Republik Indonesia; 2011.

McCharty J, Maine DA. Framework for analysis the determinants of maternal Mortality. studies in Family Planing. 1992; 23 (1): 23-33. 4. Kementerian Negara Pemberdayaan Perempuan. Angka kematian ibumelahirkan. Jakarta: 2011 [diakses tanggal 15 Februari 2016].Diunduhdalam:http://www.m enegpp. go.id/V2/index.php/datadaninforma si/ke-sehatan.

Hernandez-Correa JC. Maternal mortality and risk factors at the com-munity level. Economic Working Paper. Departement of Economics.Michigan: Western Michigan University; 2010.
Gemari. Peran ibu sangat besar bangun karakter bangsa [online]. 2009;95 [diakses tanggal 3 Desember 2012]. Diunduh dalam: www.gemari.or.id/artikel/3852.shtml. 2008

Kompasiana. Angka kematian ibu di Jawa Tengah Masih Tinggi 2012[diakses tanggal 3 Januari 2016]. Diunduh dalam: http://health.kompas.com/read/2012/12/27/09261769. 01/03/2013.

Anonim. Upaya penurunan kematian $\mathrm{ibu/BBL}$ di rumah sakit. 2012 [diakses tanggal 20 Juli 2016]. Diunduh dalam: http://id.scribd.com/doc/87322569/AKI-rakontek. 07/18/2012.

Suryawati C. Faktor sosial budaya dalam praktik perawatan kehamilan,persalinan, dan pasca persalinan (Studi di Kecamatan Bangsri Kabupaten Jepara). Jurnal Promosi Kesehatan Indonesia. 2007; 2 (1):21-31.

Aeni N. Perilaku kesehatan ibu hamil di Kabupaten Pati (Studi pada ka-sus kematian maternal tahun 2011). Jurnal Litbang. 2012; 8 (3): 200-7

Profil Dinas Kesehatan Kabupaten Tasikmalaya tahun 2014 